\title{
Erratum to: Evaluation of demineralization adjacent to orthodontic brackets after application of conventional and self-etching primer
}

\author{
Dominik Visel · Theresa Jäcker · Paul-Georg Jost-Brinkman · Thomas-Michael Präger
}

In this article, the first name for Theresa Jäcker was incorrect. In addition, Thomas-Michael Präger was not listed in the German conflict of interest.

Readers are asked to note the correct name and we apologize for the errors.

The editorial team
In diesem Beitrag wurde der Vorname von Theresa Jäcker falsch angegeben. Außerdem wurde Thomas-Michael Präger im deutschen Interessenkonflikt nicht genannt.

Wir bitten, die korrekte Nennung zu beachten und die Fehler zu entschuldigen.

Die Redaktion

\section{Corresponding address}

Dominik Visel

Department of Orthodontics, Dentofacial Orthopedics and Pedodontics, Charité - Center for Dentistry, Oral Medicine and Maxillofacial Surgery

Assmannshauser Str. 4-6, 14197 Berlin

Germany

dominikvisel@googlemail.com
Department of Orthodontics, Dentofacial Orthopedics and Pedodontics, Charité - Center for Dentistry, Oral Medicine and Maxillofacial Surgery, Berlin

published online: 19. November 2014
The online version of the original article can be found at: http://dx.doi.org/10.1007/s00056-014-0233-9 